\title{
Exploration in Dance Teaching in the Major of Preschool Education
}

\author{
Yujuan Bi \\ Department of Education, Duzhou University \\ Dezhou 253023, Shandong, China \\ Tel: 86-534-898-2209Ｅ-mail: dzbyj@163.com
}

Received: November 26, $2010 \quad$ Accepted: January 11, $2011 \quad$ doi:10.5539/ass.v7n6p154

\begin{abstract}
The preschool education major in colleges and universities is the subject to cultivate kindergarten educators. The compulsory dance class in preschool education major is a professional basic class to cultivate the ability of dance teaching of students. Dance teaching of preschool education major in colleges and universities should reform boldly in terms of course content, means and approaches based on the cultivation target and starting out from practicability. Also, dance teaching should be simple but profound, follow in proper sequence, be lively and rich in variety, mobilize the enthusiasm of students, stimulate their comprehension ability, give full play to their ability of creation and realize switch from "successive learning" to "innovative learning".
\end{abstract}

Keywords: Preschool education, Dance teaching, Kindergarten dancing

With development of the society, kindergarten education has exhibited a more and more important position. As the subject of kindergarten education, kindergarten teachers burden an important responsibility in educating and cultivating children. Without teachers with high quality, there would not be kindergarten education with high quality. The major of preschool education in colleges and universities is the subject of cultivating kindergarten educators and the compulsory dance class in preschool education major is the basic professional class to cultivate students' ability of dance teaching. However, so far as the status quo of dance education is concerned, dance teaching in the preschool education major is currently a successive teaching mode, which mainly resolves all sorts of problems in the class with traditional intrinsic teaching experience, means and principle. What is focuses is what happened in the past, rarely taking into consideration what happens at present and will happen in the future. On that account, the author believes that, preschool education should grasp the opportunity to switch from the concept of "successive learning" to the concept of "innovative learning" required by higher education, confirm the cultivation target of preschool education major in dance teaching at present, pay attention to practicality and combine the professional dance education, kindergarten teachers' qualified dance education and kindergarten education according to differences of different students.

How to cultivate the innovative spirit and development capacity of university students? How to establish a more flexible, open and scientific education mode on the basis of the traditional mode? How to make appropriate adjustment on the education modes in colleges and universities with regard to development of the society and demand on the employment market? How to reform boldly in terms of the arrangement and implementation of content of teaching material so as to fulfill the teaching target of mobilizing students' enthusiasm, stimulating students' comprehension ability and giving full play to students' creative ability? The author is going to share her own feelings and experiences based on her own dance teaching practice in the recent years.

\section{Establishment of the teaching module of "double basis"}

Different from professional training of dance in other colleges and universities, dance class in preschool education major is not only aimed at cultivating the single dance skills of students, but more importantly, to cultivate students' better kindergarten dance activity creation and design ability of students, with more stronger guidance. In order to realize this target, on the premise of taking an overall consideration of students' basic quality and dance theory culture in terms of course structure and content setting, an emphasis has to be placed on creation of kindergarten dance activities and design courses of students so as to let students be able to comprehend and grasp typical materials of different styles and different sorts within limited class hours and obtain the ability to design and guide kindergarten dance teaching activities. According to this envision, we can design a set of feasible and practical teaching module of "double basis" in dance learning of preschool education major. 


\subsection{Learning of basic theory of dance}

For the time being, students in preschool education major mostly haven't received dance education in any form during their junior and senior high schools, so they are almost blank in knowledge in dance. Even if some students have had an opportunity to receive dance education, it is nothing more than dance performance in sports class, music class and recreational activities in the spare time. As a result, they have great difficulties in accepting dance education. Considering this situation, we have to pay special attention to students' basic theory learning at the initial stage of teaching and help students master the basic characteristics and features of dance and styles of different kinds of dances, familiarize the basic technical terms of dance, master the basic methods of dance record, grasp basic theoretical knowledge of dance creation and regard theoretical knowledge of dance as the foundation of skill learning. In the meanwhile, we can make use of multimedia teaching means and observation video to help students learn excellent dance works both at home and abroad. At the time of letting students share arts, we ought to let them have certain perceptual knowledge in body action of dance works, stage blocking, the graceful dance posture of dance performers, their lingering charm and skillful movement, appreciate the charm of dance and stimulate students' interest in knowing about dance, understanding dance and learning dance and set up the confidence in learning dance.

\subsection{Basic training of dance}

The basic training of dance is the basic ability training course and is the foundation of all sorts of dance training. Basic dance training can exercise students' ability of all parts of muscles in the body, alter their original natural body pattern, liberate their body, obtain necessary skills, technique and standard movement patterns and improve their physical ability. Students of preschool education major are fresh high school graduates and they are relatively older than the appropriate age for learning dance. Their body growth has been finalized, their body flexibility, compatibility and plasticity are weakened. Besides, their dance classes are fewer than professional dance colleges. Therefore, training on students should reduce requirements on difficulty in softness, opening and bounce, etc. We should insist on the training principle of first simple and then difficult and from the shallower to the deeper, reduce such skill training as the control ability and jumping, turning and turning over in the traditional training, try to borrow the training means of modern dance regarding such positions as the head, neck, waist, arm, leg, wrist and palm as the entry pint, and combine correct postures of standing to provide the sequential combination exercise from element and dance grooves to short movements, from single movement to combined movement and from disintegrated exercise to comprehensive exercise, so as to achieve the purpose of relaxing students' body ligament and improving their body flexibility and movement harmony.

\subsection{Learning of children dance knowledge and skills}

Students of preschool education major will undertake the occupation of kindergarten education, so their mastery of relevant knowledge and skills of kindergarten education seems especially significant. Compared with professional training of dance colleges, dance class of preschool education major is stronger in pertinence. Thus, we have to pay special attention to learning and mastery of kindergarten dance knowledge of students in dance teaching. The special practice is as following: we take advantage of pre-class activities to exercise learning small children dance, alternate to learn national and folk dance at the time of learning national and folk dance, encourage students to boldly create small combination and small dances of children dance by means of homework after class, organize students to devise children dance activity plan and carry out the plan. This means which runs teaching of children dance through the entire dance teaching process extremely enriches children dance knowledge structure of students, improves students ability to master children dance knowledge and pave solid foundation for students to undertake children dance teaching in the future.

\subsection{Cultivation of children dance teaching ability}

Formerly, we often equaled single skill teaching to cultivation of all-around dance teaching ability, as a result of which some students were only able to perform dance themselves, but not able to teaching children to dance nor compile small programs of children dance. With this in mind, the author believes that, at the time when teachers teach students' basic skills in dancing, they should pay special emphasis on cultivation of students' dance teaching ability. Cultivation of dance teaching ability is an important content of dance teaching module of preschool education major, which includes such elements of designing, organizing and guiding kindergarten dance activities, etc. The specific practice is as follows: we should focus on cultivation of students' creation consciousness, lead students to start out from development characteristics of children' movement at different ages to take part in children dance activities and compile small dance programs, direct students to start out from particular education rules of children dance activities to develop dance choreography activities, combine theory and practice and improve students' ability to organize dance activities. We ought to let students understand the 
basic content of children dance teaching activities through teaching, make clear the fundamental requirements of these activities and master the basic means and methods of activities, so as to enable students to master the basic teaching principles in guiding children dance activities. Then, it is possible to really realize transfer of dance teaching in preschool education major from "development of skill" to "development of intelligence".

\section{Diversity of teaching means}

It is true that students of preschool education major are insufficient in knowledge and skills of dance, their ability to learn, comprehend and image is strong. Therefore, teachers have to be diligent in reflection and good at reflection in their teaching so as to organize and develop dance teaching activities rich in creativity.

\subsection{Teaching means guided by the concept}

Dance class is a skill class with strong operability, and meanwhile is a practice class with combination of theory and practice, which emphasizes process and exercise. as for those who just start to learn dance, traditional dance teaching is mostly centered with learning of students by simulation of movement, which is determined by the age characteristics of learners, because the optimum ages for learning dance is 11 or 12 years old, which is good at simulation but weak in comprehension. However, any for students in preschool education major in colleges and universities, their capacity in learning, understanding and imaging is good, but their ability in simulation is weak, so the focus of dance class in preschool education major is to cultivate the practical dance practice and application ability of students. Therefore, during teaching, the author, directed by teaching the concept of movement, lets students comprehend the concept of movement first of all through explanation and demonstration, helps students to comprehend the standard requirements of dance movement through accurate and correct movement demonstration of teachers, and then leads students to appreciate and experience the essentials of the movement through practical exercise. This means of teaching which guides practice with the concept and integrates closely theoretical knowledge and practice can enable students to grasp practices of the movement and skills and has gained the effect of half the work with double results in the process of teaching. For example, in teaching of picking, sinking, rinsing, relying, throwing forward, containing and moving of basic elements of dance, we firstly lead students to observe the movement and let students have a concrete image feeling and obtain the framework of the movement through explanation and demonstration of teachers. Then, we analyze the essentials of the movement in combination with exercise of the movement to enable students to correctly finish the movement based on accurate mastery of the concept. This training method which stimulates learning with theory can better explore the initiative of students in learning, combine sight and sound, sound and action and action and thinking together and let students form a new kind of thinking mode according to their own psychological experience and furthermore internalize to their peculiar body "language" which expresses their emotion with their body movement.

\subsection{Accurate teaching and appropriate teaching content}

Dance is the arts of human body and it moulds artistic image with human body movement. Thus, it is one of the important contents in dance teaching to train and improve the expressive ability of students' body to enable their body to convey or express their tender feeling very skillfully. Formation of dance skills is the process from accumulation of body capacity to improvement. Hence, in dance teaching, teachers have to avoid hankering after the speed and quantity, but should pursue accuracy and perfection, insist on making progress while ensuring stability to promote skill training and enable students to improve their body manifestation capacity in practice. Therefore, in dance teaching, the author adhered to "concise explanation of language and accurate demonstration of movement". In the process of teaching, the author firstly made clear the standard and requirement of movement to students with accurate and precise language, and then demonstrated personally with the body to fully mobilize students' visual sense and hearing sense, perceive the movement and obtain direct sensible cognition. Finally, she directed her students to repeated the exercise. This means combined by teachers' passing on by word of mouth and teaching with the body, students' subjective participation and students' exercise in different groups and personally may enable students to comprehend the essentials of the movement in repeated training, resolve difficulties and focus in the movement and then grasp and finish the movement. Simultaneously, we should adhere to the comprehensiveness and practicality of the content of teaching, and insist on the principle of being simple to difficult, being shallow to deep and following in proper sequence. According to the condition of students' body, we may appropriately delete those movements with high difficulties and strong expertise and reduce the requirement of difficulty of skill training. As for skill movements, accuracy is not required, but correct method is required, in which way students can better complete most stipulated basic movements of dance in repeated exercise and practice, and master basic material of dance. This, not only has given full play to the leading role of teachers, but also has combined the "teaching" of students together with "exercise" of students to 
generate integration of "teaching" and "learning", let students actively and passively absorb knowledge and skills taught by teachers and largely improve the dance performance competence of their body.

\subsection{Combination of "teaching" and "explaining" and complementation of "teaching" and "learning"}

The dance class of preschool education major is a professional skill class which cultivates practitioners undertaking kindergarten education and which has the practical operation and applicable competence of dance. Hence, in the process of teaching, we should cultivate the oral language expression ability of students and their capacity in teaching dance knowledge. As for problems that generally exist in training, teachers have to take measures of further explanation and demonstration and organize students to observe each other by dividing them into different groups, lead students in observation, analysis and comparison and help them more accurately master the essentials of the movement and further complete the movement. This teaching with combination of "teaching" and "explaining" can not only enable students to obtain certain professional knowledge and skills, but can also enable them to use fluent language to express the name and essentials of the movement and the methods as well as procedures. At the same time, with the method of extracurricular work, teachers can divide students into groups (10 students or so) and let students exercise what they have learnt in the class and further digest and absorb through mutual learning and assistance. When teachers examine the situation of mastery of students in the next class, they can give timely correction to problems arising. Only in this way, can teachers give full play to the subjective initiative of students as much as possible, improve students' observation ability, understanding ability and the ability to resolve problems independently, improve their interests in learning dance and attain obvious learning effects. In addition, teachers can also make full use of the last several minutes in each class to lead students making an analysis and summary on the knowledge and movement skills they have learnt, which can cultivate the oral language expression ability and the ability of teaching dance knowledge of students to attain the teaching target of complementation of "teaching" and "learning".

\section{Improving students' overall ability in activities of artistic practice}

Dance teaching in preschool education major in colleges and universities at present is to enable students to learn to meet practical needs in their work in the future. Thus, dance courses should lay emphasis on the practicality of the content taught and focus on cultivation on the comprehensive ability of students.

When students have had certain dance skills, considering the characteristics of university students in learning, thinking and proficiency in thinking, teachers should direct students to have a creative training in the existing knowledge and skills, such as, kindergarten rhythm creation, group dance creation and performance dance creation, etc. The aim is to let students to practice themselves in the exercise, obtain experiences from sensible cognition to rational cognition in the exercise and creatively employ the dance knowledge and skills they have learnt to improve their dance choreography and innovation ability. Then, they are able to learn meet practical needs and improve in a comprehensive way their overall ability. The specific practice includes the following three aspects. Firstly, we can take advantage of spare time to organize students who favor dance arts to form dance performance teams and enhance students' performance ability through learning and rehearsing excellent dance programs. Secondly, teachers should take the opportunity of students' learning, life and social activities to give full play to their creativity and imagination, provide space of independent creation for students, organize students to practice in an innovative way and independently create dance works. Thirdly, after students have finished creation of dance works, teachers should organize and lead students to carry out rehearsal plans and negotiate on the means of programs. According to requirement of the works, students can finish costume making, property making, stage image design and irrational arrangement of stage lighting, etc, and define tasks and division of labor, which should be burdened by a specific person. The works are presented to the audience in the form of stage performance, and then the entire performance is completed. Through such a series of practical activities, students may apply their dance knowledge and skills that they have mastered in the practice and the transition is completed from the basic capacity of dance of students to the dance choreography development. Students are able to give full play to their imagination and creativity by designing by themselves the costume, headwear and property, etc and their ability of operation is strengthened. Participation in performance may help students to confirm all the aspects of stage performance, master the basic rules of artistic exercise activities, accumulate experiences in artistic performance, exercise their psychological quality, strengthen their solidarity between each other, enhance their collaborative ability and reinforce the sense of honor of the collective. In such way, students' value of using what they have learnt is sufficiently embodied.

In one word, with continuous expansion of school running of preschool education major, new demands have been proposed on construction of dance courses in preschool education major. We have to set up the education idea that dance class in preschool education major is a basic quality education course, and at the time of insisting 
that dance teaching ought to help students master some dance skills, we should also have the principle of good children dance activity creation and design. In teaching design and implementation, we should regard mastery of "double basis" and concentration of improvement of children dance choreography and teaching ability as the center. In the aspect of course content arrangement, we should regard as the special operation means "guided by the concept to reduce difficulty in training and hold artistic practices". Regarding the development trend of the society in the future and requirements of employment market, we should adjust and make up for deficiency in dance teaching in preschool education major, continue to improve and perfect dance teaching system of preschool education major and cultivate graduates of this major to become new type of applicable and inter-disciplinary talents.

\section{References}

Lv, Yisheng. (2004). Dance Education. Shanghai Music Publishing House.

Sun, Guorong \& Yu, Meiyu. (2001). Guide of Dance Teaching among University Students. Shanghai Music Publishing House.

Yu, Ping. (2004). Overall Comments on Dance in Colleges and Universities. Beijing: Beijing Culture and Art Publishing House. 